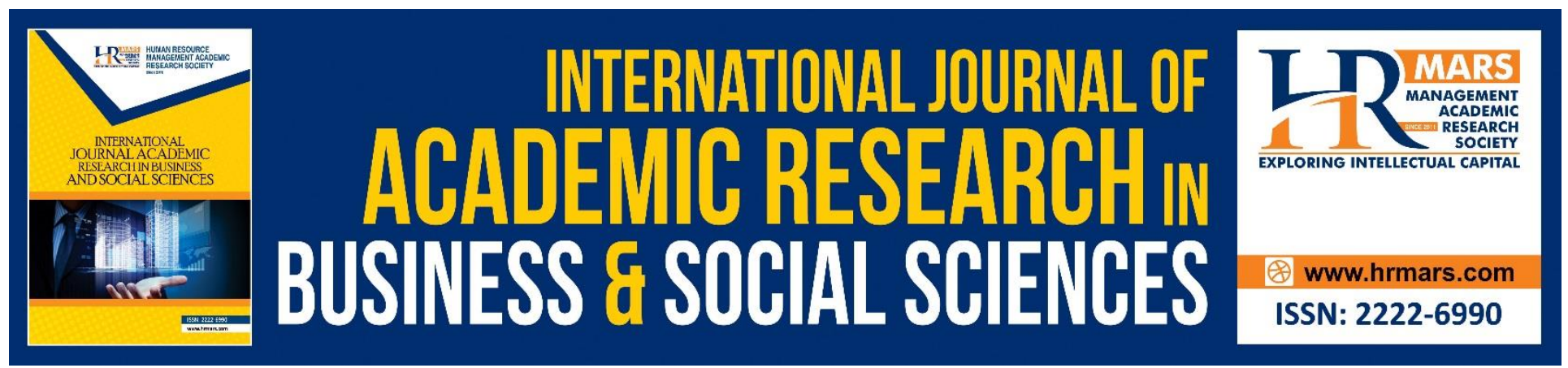

\title{
Electronic Word-Of-Mouth (eWOM) Behavior in Malaysia: Successful Marketing Strategy
}

$\mathrm{NH}$ Marmaya, BKPD Balakrishnan, ASM Shuaib

To Link this Article: http://dx.doi.org/10.6007/IJARBSS/v8-i9/4694

DOI: $\quad 10.6007 /$ IJARBSS/v8-i9/4694

Received: 13 August 2018, Revised: 29 August 2018, Accepted: 18 Sept 2018

Published Online: 15 October 2018

In-Text Citation: (Marmaya, Balakrishnan, \& Shuaib, 2018)

To Cite this Article: Marmaya, N. H., Balakrishnan, B. K. P. D., \& Shuaib, A. S. M. (2018). Electronic Word-OfMouth (eWOM) Behavior in Malaysia: Successful Marketing Strategy. International Journal of Academic Research in Business and Social Sciences, 8(9), 1244-1255.

Copyright: (C) 2018 The Author(s)

Published by Human Resource Management Academic Research Society (www.hrmars.com)

This article is published under the Creative Commons Attribution (CC BY 4.0) license. Anyone may reproduce, distribute, translate and create derivative works of this article (for both commercial and non-commercial purposes), subject to full attribution to the original publication and authors. The full terms of this license may be seen at: http://creativecommons.org/licences/by/4.0/legalcode

Vol. 8, No. 9, September 2018, Pg. 1244 - 1255

Full Terms \& Conditions of access and use can be found at http://hrmars.com/index.php/pages/detail/publication-ethics 


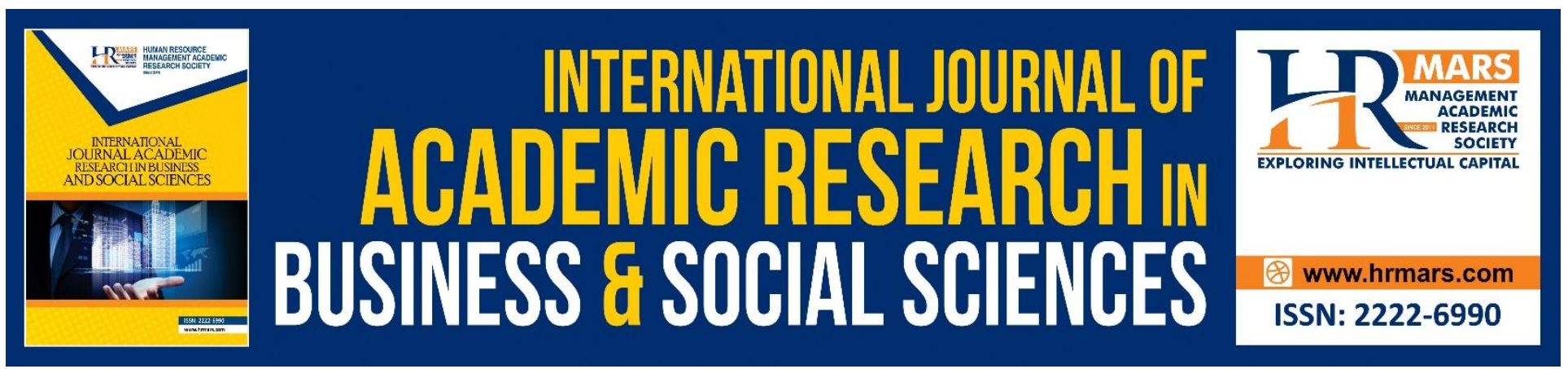

\title{
Electronic Word-Of-Mouth (eWOM) Behavior in Malaysia: Successful Marketing Strategy
}

\author{
$\mathrm{NH}$ Marmaya
}

Faculty of Business and Management, Universiti Teknologi MARA, Melaka, Malaysia

\section{BKPD Balakrishnan}

Faculty of Business, Economic and Accountancy, Universiti Malaysia Sabah, Malaysia

\section{ASM Shuaib}

Faculty of Hospitality, Tourism and Wellness, Universiti Malaysia Kelantan, Malaysia

\begin{abstract}
The major purpose of this research is to discover the influences of Active User of Social Media (AUSM), Innovativeness and Trust towards electronic word of mouth (eWOM) behaviour in Malaysia. Enormous past research on the electronic word-of-mouth, but only few have analysed the topic from Malaysian perspective. A quantitative method was adopted in this study and responses from 120 respondents in Malaysia that were analyzed using PLS-SEM. The result shows that there are significant relationship between active user of social media (AUSM), innovativeness and trust toward eWOM behaviour among Malaysian. Practically, the result indicate that electronic word of mouth behaviour via social media and mobile technology can be part of marketing strategy in promotion to influence buyer to increase sales of product of a company. This empirical study attempts to enrich the understanding of electronic word of mouth behaviour via social media and mobile technology in Malaysian context.
\end{abstract}

Keywords: Words of Mouth, Social Media, Active User of Social Media (AUSM), Innovativeness and Trust

\section{Introduction}

As reported by The News Straits times in September 22, 2018, The Entrepreneur Development Ministry of Malaysia aims to provide proper training for entrepreneurs, while also acting as a coordinating body for agencies under its purview in a bid to strengthen the contribution of entrepreneurs to the economy (Bernama, 2018). Successful marketing strategy is one of the factors that could strengthen entrepreneurs to more competitive in their business. Marketing communications through social media is playing an important role in current marketing strategy and 
are much more fluid than the offline counterpart. It relies more on instinct than on a rigid planning process. One of the reasons given is that the marketing environment changes so often and developments in the media make marketers to react to those developments and generate content that interests the audience. Internet has transformed our daily activities and communications with people. This interaction is transforming the manner of people in the way they communicate, because we could reach others from all around the world with just one click. Word-of-mouth is defined as oral, person-to-person communication between a receiver and a communicator, whom the receiver perceives as non-commercial, regarding a brand, product, or service. This definition tries to define the research boundary of word-of-mouth study, and put emphasis that word-of-mouth is oral and non-commercial. The Internet has enabled new forms of communication platforms that further empower both providers and consumers, allowing a vehicle for the sharing of information and opinions both from business to consumer, and from consumer to consumer. eWOM refers to any positive or negative statement made by potential, actual, or former customers about a product or company, which is made available to a multitude of people and institution. Particularly, traditional WOM has developed into a new form of communication: electronic word-of-mouth communication (eWOM), in which online social networking has turned into a worldwide phenomenon and major part of the everyday activities of many purchasers around the globe. Along with traditional email interaction, blogs, message boards, chat rooms, social networking sites and instant messaging, there has been a formation of online communities where people connect, communicate, follow current issues and convey their viewpoints more openly and actively than ever before across the world. Broadband access, mobile communication instruments and easy-to-use software technology have permitted purchasers to obtain their opinions heard immediately, exert substantial impact on matters that important to them (issues that offer practical and emotional benefits) and deliver important information by either volunteering (online product ratings and reviews) or on-demand when requested by others. Studies indicate that more than a third of online participants review products, frequently post opinions and participate in online content formation activities. Existing literatures about the effect of eWOM could be classified into two kinds. One is based on the view of consumers, which study on how eWOM influences consumers' attitude and purchase behavior. The other is based on the view of corporates, which focus on how eWOM influences corporates' reputation, revenue and customer equity (Li, Jie; Xue, Wenyi; Yang, Fang; and Li, Yakun, 2016). Even though electronic word of mouth has shown its success towards consumer viewpoint and behaviour, it is still at a beginner's status, and further research needs to be carried out. The research with eWOM is still emerging (Li, Jie; Xue, Wenyi; Yang, Fang; and Li, Yakun, 2016), thus further study is recommended so as to improve the understanding on the relative impacts of the elements on the responses of eWOM's effect. In addition, eWOM will help the entrepreneurs to do their marketing strategy better. In relation to that, current study is focusing on factors influence of eWOM among Malaysian consumers view.

\section{Literature Review}

\section{The impact of Electronic Word of Mouth (eWOM) on consumers}

eWOM has been acknowledged by many researchers to have a significant impact on consumers (Fergusson, 2008; Sung et al., 2008 cited in Hongwei, et al., 2012). eWOM is recognized to build 
consumers' brand awareness, helps a company to create buzz (Fergusson, 2008) and has an effect on consumers' brand loyalty (Sung, et al., 2008 cited in Hongwei, et al., 2012). It was indicated by a study that social media and mobile technology have become important mediums of information interchange prior to purchases (Lee et al., 2013; Kwon et al., 2011), and online dealings are main facets of the modern customer experience (Nusair et al., 2013). Both Trip Advisor and Facebook are buyer-generated content which it is conveyed through progressively marketable social networking websites (Berezina \& Bilgihan, 2015). This particular information interchange mediums have altered the manner in which buyers analyse information absorbed from buyer-centric communities by letting them to share their experiences, thus improving online social influences and eWOM (Chu and Kim, 2011; Zhang et al., 2017). The eWOM takes place in a more complex computer-mediated context, whereas traditional WOM typically happens in a face-to-face/one-on-one context. With traditional WOM, participants are in close proximity, and these conversations are often private in nature. On the other hand, participants engage in communication with a network of people with eWOM in online communities where conversations are more visible. It is perceived well by academics and practitioners that electronic word-of-mouth (eWOM) marketing is a useful marketing strategy (Chu and Kim, 2011). eWOM marketing is attractive because it conquers consumer resistance, importantly costs low and convey quick - specifically via technology such as social media and mobile technologies. eWOM is described as the process that enable purchasers to express their thoughts through online and directs purchasers to favour and go against particular products. eWOM comprises open communications from purchasers regarding the attributes and features of products or brands. It is specifically significant feature in concurrent communication instruments, such as social media and mobile technologies. For instance, a pioneering company, Starbucks invested in eWOM marketing campaigns by developing their social media existence and nurturing customer feedbacks and recommendations (Chua and Banerjee, 2013). While eWOM interaction has some attributes in similar with traditional word of mouth (WOM) communication, it is dissimilar from traditional WOM in a number dimensions. These dimensions attribute to the uniqueness of eWOM communication. Firstly, unlike traditional WOM, eWOM communications own revolutionary scalability and rate of diffusion. As with WOM, sharing of knowledge is between small communities of individuals in simultaneous mode (Avery, Resnick, and Zeckhauser, 1999; Dellarocas 2003). Nevertheless, eWOM communications include several ways exchanges of knowledge in a simultaneous mode (Hung and $\mathrm{Li}$, 2007). The use of diverse electronic technologies such as online discussion forum, electronic bulletin board, newsgroups, blogs, review sites and social networking sites enable the knowledge exchange among communicators (Goldsmith, 1991). Secondly, contradict to traditional WOM, eWOM communications are more persistence and reachable. Thirdly, eWOM communications are more quantifiable than traditional WOM. The demonstration of the format, quantity and persistence of eWOM communications have made them more visible. Word-of-mouth information obtainable online is way more capacious in quantity contrast to information acquired from traditional contacts in the offline setting. Lastly, traditional WOM transmit from a sender who is known to the receiver of the information, so that the reliability of the communicator and the message is known to the receiver. 


\section{Active user of Social Media (AUSM)}

Social media is referring categorically to sites that are designated as buyer and or customer-based community services where people can design a public profile, interacts with peers and convey personal experiences and opinions inside the digital community (Berezina et al., 2015; Hoffman and Soyez, 2010; Lee et al., 2013). According to this explanation, social media underlines the foundation of social interactions among people with the same interests and activities and who communicate in online interactions. A desire to communicate with friends is an important rationale in most developed countries uses social media. People, who are aged 21 to 35 years, if they are backed by sound information connection infrastructure, would pick to use social networking and mobile technology to communicate with associates, friends and family. They are also more probably to appreciate the information in social media and to feel appraised when they engage in response about the products they use. The reason of this active use of social networking instruments is to communicate and interact with other buyers and the outside world. Consequently, if they experience good service at a restaurant, hotel or a retail store, they engage typically in positive eWOM within their online communities via mobile technologies or other methods of communication. On the other hand, if they encounter poor service, also referred to as service failure, they will disseminate negative eWOM to their peers or families to express their complaints or emotional reactions, such as anger, unhappiness and dissatisfaction. It is a general rule that service failure can be countered by good service recovery packages delivered in a timely manner (Zhang, Omran, \& Cobanoglu, 2017). H1: Active User of Social Media (AUSM) influence Electronic Words of Mouth (eWOM)

\section{Innovativeness}

Innovativeness means to an individual's implicit level of uniqueness seeking and shows his or her identity and propensity toward innovation (Okazaki, 2009). Innovative purchasers are more probably to view new technology enthusiastically and be inspired to use such products (Dabholkar and Bagozzi, 2002). Antecedent studies have showed that a person with high levels of innovativeness is more likely to seek for information about new products and convey their discoveries with others which shows that autonomous external motivation (e.g. the desire to keep up with the latest technology and information) can increase intrinsic motivation (Lee et al., 2013). One main reason is that connecting in eWOM on social media might give members unanticipated positive response from others on innovative tasks they are undertaking, by that further accelerating their internal motivation to accomplish those tasks. Facebook users with greater innovativeness are prone to be opinion leaders rather than opinion seekers (Tsang and Zhou, 2005). With the opinion leader, greater innovativeness is useful because being original is necessary, as an individual tend to pursue what is trendy. Not to forget, on a psychographic level, opinion leaders are acclaimed to be more innovative than nonleaders (Tsang and Zhou, 2005).

H2: Innovativeness influence Electronic Words of Mouth (eWOM)

\section{Trust}

Trust helps an individual's assurance and willingness to gain faith in another party (Lien et al., 2014). Indeed, Lu et al. (2010) observed trust in both online community members and trust in the platform as antecedents of buyer to buyer purchase intention in virtual communities. Pavlou and Dimoka 
(2006) examined the progress of trust creation between a consumer and a private merchant on eBay (which differs from context, in which the reviewer ostensibly has no interest in the consumer's purchase decision), and prove that response mechanisms impact trust, which in turn effected not only purchase intention, but also drove to willingness to spend on price premiums. Consumers are prone to trust their peers on Facebook rather than expert opinions on blogs or product review pages with opinions (Chu and Kim, 2011). Instead of reading undisclosed reviews of others, comments posted by Facebook peers may be recognized as more honest and trustworthy. Lu et al. (2010) break down trust into two different segments; the first one is trust in the Web site and the second one is trust in members. According to them, while trust in the Web site relates to the confidence that the Web site or the virtual community sponsor is capable of contributing quality services and would do good to its users, trust in members can be a predominance factor that influence the growth and success of virtual communities, as in a virtual situation where members are usually unidentified and do not communicate in direct face-to-face communication, trust could be an important matter. They also indicate that in virtual communities, trust plays crucial part in influencing members' attitude, as an individual would behave proactively when they trust the situation and other people. Thus, perceived trust should be evaluated as one of the factors that influence consumers' engagement behaviour in online word-of-mouth communication. Trust helps a person's self-assurance and readiness to have belief in another party (Lien et al., 2014). While trust has been commonly studied in e-commerce, it has also been an important component of the e-WOM model, with many authors connecting the trust capability of reviews to buying intention (e.g. Cheung et al., 2009). King et al. (2014) examined the impact of features of the review or reviewer on the event of trust in the reviewer when examining online reviews. Racherla et al. (2012) exhibited that review argument quality and also the degree to which the reviewer recognizes them both affect trust formation. Trust also impacts whether consumers attract in interpersonal interaction in virtual groups and online social networks (Chiu et al., 2006; Chu and Choi, 2011). Hence, eWOM, through the growth of product and service knowledge from an individual to an individual through online social networks, is counted believable (Chu and Kim, 2011) because members of the similar social network incline to trust towards each other more than they trust people who are not in the network.

Hypothesis 3: Trust influence Electronic Words of Mouth (eWOM)

\section{Methodology}

\section{Measurement}

The measurements are developed based on extensive reviews of the literature. The survey is divided into two sections: the first section is designed to collect information on respondents' demographic profile, while the second section contains measurements on theoretical constructs for the present study. Second section consists of questions related to social media (AUSM) (Ye et al., 2011), innovativeness by Midgley and Dowling (1978) and trust by Lu et al. (2010) and the electronic word of mouth (eWOM) behavior by Heung and Lam (2003). The survey is measured using the five-point Likert scale (i.e. $1=$ strongly disagree and $5=$ strongly agree). A pre-test study is carried out using 50 respondents. The respondents are a relatively homogeneous population suitable for theory testing and development. They also represent a growing target market for the research context and are 
INTERNATIONAL JOURNAL OF ACADEMIC RESEARCH IN BUSINESS AND SOCIAL SCIENCES

Vol. 8, No. 9, Sept. 2018, E-ISSN: 2222-6990 @ 2018 HRMARS

therefore considered appropriate for the present study. From this initial pretest, several questions are rephrased to improve the instrument's readability.

\section{Sample}

The present study distributes a total of 130 questionnaires. The collected responses are later screened and examined for incomplete responses and credibility. This initial procedure has resulted in the removal of 10 incomplete or unreliable responses (i.e. out of 130), thus leaving a total of 120 usable responses. The data obtained are analysed using Smart PLS 2.0, which was developed by Ringle et al. (2005), which then received rich empirical support by various studies in Malaysia (Ramayah et al., 2011). PLS commonly can be extended to both large and small samples without a concern of normality of data. Marcoulides and Saunders (2006) have proven that PLS does not impose sample size restrictions for the underlying data.

\section{Results}

Most of the respondents are female (65.5\%) followed by male (34.5\%) with bachelor degree as the highest educational background (15\%), followed by diploma (60.5\%) and SPM level (24.5\%). Most of the respondents are between $31-35$ and 36-40 years old which contribute $31.0 \%$ and $29 \%$ consequently, of the total respondents whereas the second highest would be between 26-31 years old with $22.5 \%$ and number of respondents at age $20-25$ years old contribute the remaining $17.5 \%$. Data analysis following Anderson and Gerbing (1988), data analysis is conducted using two-stage approach, namely, measurement and structural model. The details are as follows:

\section{Measurement Model}

The measurement model analysis is conducted for construct validity. Construct validity is composed of two components of convergent and discriminant validity. Convergent validity analysis comprises of average variance extracted (AVE) and composite reliability (CR). One item was deleted (AUSM1) due to lower loading than the threshold value of 0.6 (Hair et al., 2010). The remaining 30 items produce satisfactory results. The reliability coefficient of factor structures is measured using the Cronbach's alpha. The coefficient alpha values for the five constructs range from 0.54 to 0.95 , demonstrating good internal consistency and strong reliability of each dimension (Hair et al., 2010). The constructs' validity is further examined using the convergent analysis. The results suggest strong convergent validity. Specifically, the computation of AVE ranges from 0.50 to 0.81 , higher than the Fornell and Larcker's (1981) recommended value of 0.50. The reported CR exceeds the recommended value of 0.7 (Hair et al., 2012). Collectively, these results provide good support for soundness of scale structures (Table 1). 
INTERNATIONAL JOURNAL OF ACADEMIC RESEARCH IN BUSINESS AND SOCIAL SCIENCES Vol. 8, No. 9, Sept. 2018, E-ISSN: 2222-6990 @ 2018 HRMARS

Table 1: Construct Reliability and Validity

\begin{tabular}{lccc} 
& $\begin{array}{c}\text { Cronbach's } \\
\text { Alpha }\end{array}$ & $\begin{array}{c}\text { Composite } \\
\text { Reliability }\end{array}$ & $\begin{array}{c}\text { Average Variance } \\
\text { Extracted (AVE) }\end{array}$ \\
\hline AUSM & 0.539 & 0.790 & 0.660 \\
\hline INNOVATIVENESS & 0.915 & 0.930 & 0.598 \\
\hline TRUST & 0.952 & 0.961 & 0.806 \\
\hline eWOM & 0.812 & 0.860 & 0.501
\end{tabular}

Table 2 reports meeting the discriminant validity testing (Fornell and Larcker, 1981). The results depict that the values in diagonal exceeding the threshold value of 0.70 demonstrate adequate discriminant validity.

Table 2: Discriminant Validity

\begin{tabular}{lccc|c} 
& AUSM & INNOVATIVENESS & TRUST & eWOM \\
\hline AUSM & 0.813 & & & \\
\hline INNOVATIVENESS & 0.167 & 0.774 & & \\
\hline TRUST & 0.308 & 0.396 & 0.897 & \\
\hline eWOM & 0.403 & 0.616 & 0.494 & 0.702 \\
\hline
\end{tabular}

\section{Structural Analysis}

Table 3, shows the results of the hypotheses relationships. The analysis suggests a strong support on three of our posited hypotheses (i.e. $\mathrm{H} 1, \mathrm{H} 2$ and $\mathrm{H} 3$ ). The analysis of $\mathrm{R}^{2}$ for eWOM is 0.51 . The result discovers that 52.1 per cent of the variation for eWOM could be explained by the dimension of AUSM, innovativeness and trust. Following Hair et al. (2011), $\mathrm{R}^{2}$ values meet the requirement of 0.2 or 20 per cent in the consumers' research, suggesting that the current model is acceptable.

Table 3: Hypotheses testing

\begin{tabular}{lcccc} 
Hypotheses & $\begin{array}{c}\text { Original } \\
\text { Sample }\end{array}$ & $\begin{array}{c}\mathbf{T} \\
\text { Statistics }\end{array}$ & $\begin{array}{c}\mathbf{P} \\
\text { Values }\end{array}$ & $\begin{array}{c}\text { Hypothesis } \\
\text { accepted/rejected }\end{array}$ \\
\hline H1:AUSM influence eWOM & 0.252 & 3.468 & 0.000 & Accepted \\
\hline $\begin{array}{l}\text { H2: Innovativeness influence } \\
\text { eWOM }\end{array}$ & 0.486 & 8.026 & 0.001 & Accepted \\
\hline H3:Trust influence eWOM & 0.225 & 2.808 & 0.003 & Accepted
\end{tabular}

\section{Discussion}

The study aimed to present the impact of active use of social media (AUSM), innovativeness and trust on eWOM. The first hypothesis discovers a significant relationship between active use of social media (AUSM) on eWOM. The positive relationship of AUSM was supported by previous researcher (Kucukemiroglu and Kara (2015). These findings appear to suggest that Malaysian consumers who are active user of social media (AUSM) inclined to disseminate electronic word of mouth (eWOM) 
whether the experienced positive, negative or satisfactory recovery following a service failure (Zhang, Omran, \& Cobanoglu, 2017). The result of this study also shows that innovativeness influence electronic word of mouth. This is consistent with the findings of Kucukemiroglu, and Kara (2015) who revealed that a person with high levels of innovativeness is more likely to seek information about new products and convey their discoveries with others. Besides that, this finding confirms previous research that recommends people who are prone to new ideas are heavy users' social communication, which is the prompt internal motivation to engage in word of mouth activity. Hence, innovativeness is one of the factors that influence consumers in Malaysia to use electronic word of mouth behavior. This study also discovers a relationship between trust and eWOM. This result supported by Kucukemiroglu, \& Kara, (2015) who found that in virtual communities, trust plays a crucial part in influencing members' attitude, as an individual would behave proactively when they trust the situation and other people. Besides that, when two persons start to trust towards each other, they become more comfortable to convey their resources without afraid of being exploited by their peer. Thus, trust is one of the factors that influence Malaysian consumers to use electronic word of mouth behaviour.

\section{Conclusion}

This study discovers the concept of eWOM to determine the factors that have an effect on one of the successful marketing strategy. Research has shown that when it comes to successful marketing strategy, active use of social media (AUSM), innovativeness and trust become the major factor to influence eWOM. This study also has developed an understanding the importance of eWOM in Malaysia. Better understanding of consumers' attitudinal-behavioural dispositions towards eWOM in Malaysia offers critical information about factors that make people may want to post or share eWOM reviews, which in-turn provides more information about a product. These findings help SMEs and marketers to develop strategic plans for future applications. In addition, under the network environment, the eWOM is the truest reflection of consumers' product evaluation and enterprises should concern about the eWOM and get consumers' opinion of the brand to improve brand competition force constantly. The findings also give useful understanding to managers and marketing strategy decision-makers that social networking sites, such as Facebook, Twitter, Instagram and many more should be the important element of the communication process and need to be utilised strategically to support the overall marketing communication purposes. Besides that, marketers should be part of the social networks of their potential customers and build one-on-one marketing communication to help customers. They should analyse consumer online behaviour and track opinion seekers to develop close relationships with them. The outcome of the study is hopefully able to serve as a useful reference to SMEs, marketers, managers and Malaysian statutory bodies on the current scenario in marketing. To inculcate the better understanding about eWOM, Ministry of Entrepreneurial Development, Malaysia should increase knowledge and awareness among entrepreneurs by providing them a proper training on eWOM. This is identical with the aim of the ministry to facilitate the development of entrepreneurs, especially small and medium enterprises, and monitor their performance, as well as reaching out to those who were keen to advance themselves (Bernama,2018). 
INTERNATIONAL JOURNAL OF ACADEMIC RESEARCH IN BUSINESS AND SOCIAL SCIENCES Vol. 8, No. 9, Sept. 2018, E-ISSN: 2222-6990 @ 2018 HRMARS

Some limitations should be acknowledged. First, the limited time for data collection and questionnaire surveys was the key limitation for this study. The sample obtained only from Melaka, Kuala Lumpur, Johor and Negeri Sembilan that indicates the generalisation issue. Secondly, this results in a relatively small size (120), compared with the population size. Therefore, future studies should attempt to reach larger groups of respondents including Sabah and Sarawak to validate the theoretical linkage tested in the present study. This also might affect the representative of the outcomes. The difference between different groups of respondents (female vs male, different age groups, Borneo vs Peninsular of Malaysia) also could be examined in the future. Also, the research model can be tested in different culture environment and investigates if people with different cultural background may assess eWOM in different ways.

\section{References}

Anderson, J. and Gerbing, D. (1988). Structural Modeling in Practice: A Review and Recommended Two Step Approach. Psychological Bulletin, Vol. 103 No. 3, pp. 411

Avery, Chris, Paul Resnick, and Richard Zeckhauser (1999). The Market for Evaluations. American Economic Review, Vol. 89(3) 564-584.

Berezina, K., \& Bilgihan, A. (2015). Understanding Satisfied and Dissatisfied Hotel Customers: Text Mining of Online Hotel Reviews. Journal of Hospitality Marketing \& Management, 1-24

Cheung, M., Luo, C., Sia, C., \& Chen, H. (2009). Credibility of electronic word-of-mouth: informational and normative determinants of on-line consumer recommendations. International Journal of Electronic Commerce, 13(4), 9-38. http://dx.doi.org/10.2753/JEC1086-4415130402

Chu, S.C., \& Choi, M. S. (2011). Electronic Word-of-Mouth in Social Networking Sites: A Cross-Cultural Study of the United States and China. Journal of Global Marketing, 263-281.

Chu, S. C., \& Kim, Y. (2011). Determinants of Consumer Engagement in Electronic Word-of-Mouth (eWOM) in Social Networking Sites. International Journal of Advertising, 30(1) , 47-75.

Chua , A. Y., \& Banerjee , S. (2013). Customer Knowledge Management Via Social Media: the Case of Starbucks. Journal of Knowledge Management, 237-249.

Dabholkar and Bagozzi (2002). An Attitudinal Model of Technology-based self-service: Moderating effect consumer traits and situational factors, Academy of Marketing Science Journal, 184

Dellarocas, C. (2003). The Digitization of Word of Mouth: Promise and Challenges of Online Feedback Mechanisms. Management Science, 49(10), 1407- 1424

Fergusson, R., 2008. Word of mouth and viral marketing: taking the temperature of the hottest trends in marketing. Journal of Consumer Marketing, 25 (3), pp.179-82

Fornell, C. and Larcker, D.F. (1981), "Evaluating Structural Equation Models with Unobservable Variables and Measurement Error, Journal of Marketing Research,Vol. 18 No. 1, pp. 39-50.

Goldsmith, R.E. \& Hofacker, C.F. (1991). Measuring Consumer Innovativeness, Journal of the Academy of Marketing Science, 19, 209-221.

Hair, J.F., Black, W.C., Babin, B.J. and Anderson, R.E. (2010). Multivariate Data Analysis. 7th ed.,Prentice Hall, Englewood Cliffs

Hair, J.F., Sarstedt, M., Ringle, C.M. and Mena, J.A. (2012). An Assessment of the Use of Partial Least Squares Structural Equation Modeling in Marketing Research", Journal of the Academy of Marketing Science, Vol. 40 No. 3, pp. 414-433 
INTERNATIONAL JOURNAL OF ACADEMIC RESEARCH IN BUSINESS AND SOCIAL SCIENCES Vol. 8, No. 9, Sept. 2018, E-ISSN: 2222-6990 @ 2018 HRMARS

Heung, V.C. and Lam, T. (2003), "Customer complaint behaviour towards hotel restaurant services", International Journal of Contemporary Hospitality Management, Vol. 15 No. 5, pp. 283-289

Hoffman, S., \& Soyez, K. (2010).A Cognitive Model to Predict Domain-Specific Consumer Innovativeness. Journal of Business Research, 778-785

Hongwei, Y., Hui, L., \& Liuning, Z., 2012. Predicting young Chinese consumers' mobile viral attitudes, intents and behavior. Asia Pacific Journal of Marketing and Logistics, 24 (1), pp.59 - 77

Hung, K. and Li, S.Y. (2007). The influence of eWOM on Virtual Consumer Communities: Social Capital, Consumer Learning, and Behavioral Outcomes", Journal of Advertising Research, Vol. 47 No. 4, pp. 485-495

King, R.A., Racherla, P. and Bush, V.D. (2014), "What we know and don't know about online wordofmouth: A review and synthesis of the literature". Journal of Interactive Marketing, Vol. 28, No. 3, pp. 167-183. http://dx.doi.org/10.1016/j.intmar.2014.02.001

Kucukemiroglu, S., \& Kara, A. (2015).Online Word-of-Mouth Communication on Social Networking Sites. pp.2-20.

Kwon T., (2011). MSblender: A Probabilistic Approach for Integrating Peptide Identifications from Multiple Database Search Engines. J Proteome Res. 10(7) 2949-2958.

Lee, W,.Tyrell, T., \& Erdem, M., (2013). Exploring the Behavioral Aspects of Adopting Technology: Meeting Planners' Use of Social Network Media and the Impact of Perceived Critical Mass. Journal of Hospitality and Tourism Technology, 6-22.

Li, Jie; Xue, Wenyi; Yang, Fang; and Li, Yakun, (2016). "A Research Review on Effect of eWOM" . WHICEB 2016 Proceedings.

Lien, C.H. and Cao, Y. (2014), "Examining WeChat users' motivations, trust, attitudes, and positive word-of-mouth: evidence from China", Computers in Human Behavior, Vol. 41 No. 6, pp. 104-11.

Lu , Y. Zhao, L. Wang, Bin,(2010), From virtual community members to C2C e-commerce buyers: Trust in virtual communities and its effect on consumers' purchase intention. Electronic Commerce Research and Applications, 9 pp, 346-360

Marcoulides, George A. and Saunders, Carol. 2006. "PLS: A Silver Bullet?," MIS Quarterly, (30: 2).

Midgley, D.F., Dowling, G.R. (1978) Innovativeness: The concept and its measurement. Journal of Consumer Research 4(4):229-242

Nusair, K.,Bilgihan, A., \& Okumus, F. (2013). The Role of Online Social Network Travel Websites in Creating Social Interaction for Gen Y travelers.International Journal of Tourism Research, 458-472.

Okazaki, S. (2009). 'The Tactical Use of Mobile Marketing: How Adolescents' Social Networiking Can Best Sliape Brand Extensions,' Journal of Advertising Research, 49, (1), 12-38.

Pavlou, P.A. and Dimoka, A. (2006), "The Nature and Role of Feedback Text Comments in Online Marketplaces: Implications for Trust Building, Price Premiums, and Seller Differentiation," Information Systems Research, 17, 4, 392-414

Racherla, P. \& Friske, W. (2012). Perceived Usefulness of Online Consumer Reviews: An Exploratory Investigation across Three Service Categories. Electronic Commerce Research and Applications, 11 (6), 548-559. 
Ramayah, T., Lee, J.W.C. and In, J.B.C. (2011). Network Collaboration and Performance in the Tourism Sector", Journal of Service Business, Vol. 5 No. 4, pp. 411-428.

Ringle, C., Wende, S., and Will, A. (2005). Customer segmentation with FIMIX-PLS. In T. Aluja, J.

Casanovas, V. Esposito Vinzi, A. Morineau, and M. Tenenhaus Eds., Proceedings of PLS-05

International Symposium, SPAD Test\&go, Paris, pp. 507-514.

Shu-Chuan C., \& Yoojung K (2011). Determinants of Consumer Engagement in Electronic Word-ofmouth (eWOM) in Social Networking Sites. International Journal of Marketing, 30(1) 47-75

Bernama. (2015). Entrepreneur development ministry to train entrepreneurs [online] Available https://www.nst.com.my/news/nation

Tsang, A.S.L. and Zhou, N. (2005). Newsgroup Participants as Opinion Leaders and Seekers in Online and Offline Communication Environments. Journal of Business Research. Vol. 58 No. 9, pp. 1186-1193.

Ye, Q., Law, R., Gu, B., \& Chen, W. (2011). The influence of user-generated content on traveler behavior: An empirical investigation on the effects of e-Word-of-Mouth to hotel online bookings. Computers in Human Behavior, 27, 634-639.

Zhang, T., Omran, B. A., \& Cobanoglu, C., (2017). Generation Y's Positive and Negative eWOM: Use of Social Media and Mobile Technology, 732-761.

\section{Corresponding Author}

Dr. Najihah Hanisah bte Marmaya

UiTM Cawangan Melaka, Kampus Bandaraya Melaka

110 Off Jalan Hang Tuah

75300 Melaka, MALAYSIA

Email: najihah_02@yahoo.com 